\title{
A Smac-mimetic sensitizes prostate cancer cells to TRAIL-induced apoptosis via modulating both IAPs and NF-kappaB Yao Dai ${ }^{\dagger 1,4}$, Meilan Liu ${ }^{\dagger 2}$, Wenhua Tang1, Yongming Li ${ }^{1}$, Jiqin Lian ${ }^{1}$, Theodore S Lawrence ${ }^{1,3}$ and Liang $\mathrm{Xu}^{* 1,3}$
}

\begin{abstract}
Address: ${ }^{1}$ Department of Radiation Oncology, University of Michigan, Ann Arbor, MI 48109, USA, ${ }^{2}$ Department of Pathology, University of Michigan, Ann Arbor, MI 48109, USA, ${ }^{3}$ Comprehensive Cancer Center, University of Michigan, Ann Arbor, MI 48109, USA and ${ }^{4}$ Current address : Department of Radiation Oncology, University of Florida Health Science Center, Gainesville, FL 32610

Email: Yao Dai - daiyao@umich.edu; Meilan Liu - lmiu@umich.edu; Wenhua Tang - wenhuat@med.umich.edu;

Yongming Li - yongmli@umich.edu; Jiqin Lian - lianj@umich.edu; Theodore S Lawrence - tsl@umich.edu; Liang Xu* - liangxu@umich.edu

* Corresponding author †Equal contributors
\end{abstract}

Published: 6 November 2009

BMC Cancer 2009, 9:392 doi:10.1 186/147|-2407-9-392
Received: 30 October 2008

Accepted: 6 November 2009

This article is available from: http://www.biomedcentral.com//47/-2407/9/392

(c) 2009 Dai et al; licensee BioMed Central Ltd.

This is an Open Access article distributed under the terms of the Creative Commons Attribution License (http://creativecommons.org/licenses/by/2.0), which permits unrestricted use, distribution, and reproduction in any medium, provided the original work is properly cited.

\begin{abstract}
Background: Although tumor necrosis factor-related apoptosis-inducing ligand (TRAIL) is a promising agent for human cancer therapy, prostate cancer still remains resistant to TRAIL. Both X-linked inhibitor of apoptosis (XIAP) and nuclear factor-kappaB function as key negative regulators of TRAIL signaling. In this study, we evaluated the effect of SHI22, a small molecule mimetic of the second mitochondria-derived activator of caspases (Smac), on TRAIL-induced apoptosis in prostate cancer cells.
\end{abstract}

Methods: The potential of Smac-mimetics to bind XIAP or cIAP-I was examined by pull-down assay. Cytotoxicity of TRAIL and/or Smac-mimetics was determined by a standard cell growth assay. Silencing of XIAP or cIAP-I was achieved by transient transfection of short hairpin RNA. Apoptosis was detected by Annexin V-PI staining followed by flow cytometry and by Western Blot analysis of caspases, PARP and Bid. NF-kappaB activation was determined by subcellular fractionation, real time RT-PCR and reporter assay.

Results: SH I22, but not its inactive analog, binds to XIAP and CIAP-I. SHI22 significantly sensitized prostate cancer cells to TRAIL-mediated cell death. Moreover, $\mathrm{SH} 22$ enhanced TRAIL-induced apoptosis via both the death receptor and the mitochondrial pathway. Knockdown of both XIAP and cIAP-I sensitized cellular response to TRAIL. XIAP-knockdown attenuated sensitivity of SHI 22 to TRAIL-induced cytotoxicity, confirming that XIAP is an important target for IAP-inhibitormediated TRAIL sensitization. SHI22 also suppressed TRAIL-induced NF-kappaB activation by preventing cytosolic IkappaB-alpha degradation and RelA nuclear translocation, as well as by suppressing NF-kappaB target gene expression.

Conclusion: These results demonstrate that $\mathrm{SHI} 22$ sensitizes human prostate cancer cells to TRAIL-induced apoptosis by mimicking Smac and blocking both IAPs and NF-kappaB. Modulating IAPs may represent a promising approach to overcoming TRAIL-resistance in human prostate cancer with constitutively active NF-kappaB signaling. 


\section{Background}

Primary or acquired resistance of prostate cancer to current treatment protocols has been associated with apoptosis-resistance in cancer cells, leading to therapy failure $[1,2]$. Tumor necrosis factor-related apoptosis-inducing ligand (TRAIL) is a member of the TNF family that is in clinical trials for the treatment of prostate cancer, either alone or in combination with other treatments [3]. TRAIL selectively induces apoptosis in prostate cancer cells compared to normal prostate epithelial cells [4]. The relative resistance of normal cells to TRAIL has been explained by the lower expression levels of functional death receptors relative to cancer cells $[5,6]$. Hence, TRAIL exerts a selective antitumor activity without eliciting systemic toxicity in multiple preclinical models, and is considered to be a prime candidate for prostate cancer therapy [3].

Mechanistically, TRAIL triggers apoptosis via binding to its functional death receptors DR4 and DR5, and activating both death receptor (extrinsic) and mitochondria (intrinsic) apoptosis pathways [7]. Ligation of DR4/DR5 by TRAIL results in caspase- 8 activation and directly cleaves downstream effector caspases [8]. Signals originating from death receptors can be linked to mitochondria via Bid, which causes mitochondrial cytochrome c release and caspase-9 activation. The mitochondrial pathway is engaged by the release of multiple pro-apoptotic factors from mitochondria into the cytosol, such as cytochrome c, Smac and apoptosis inducing factor (AIF). These factors execute cells through apoptosis in either a caspasedependent or independent manner [9].

Despite the fact that TRAIL selectively induces apoptosis in cancer cells, TRAIL-resistance has been observed in a substantial number of cancers, including prostate cancer [10]. It is widely accepted that the inhibitor of apoptosis proteins (IAP) function as a key negative regulator in TRAIL resistance $[11,12]$. Mounting evidence confirms that XIAP, the most potent anti-apoptotic protein among IAPs, is responsible for primary or acquired TRAIL resistance in tumor cells [13-16]. Overexpression of XIAP increases resistance to TRAIL-induced apoptosis, while downregulation of XIAP restores responsiveness to TRAIL $[17,18]$. At the transcriptional level, almost all IAP proteins are driven by the upstream transcription factor NFkappa B (NF- $\kappa \mathrm{B})$, which can be stimulated by multiple stimuli, including TRAIL [19]. TRAIL-induced NF- $\kappa$ B activation attenuates apoptosis, predominantly by upregulating various anti-apoptotic proteins, including IAPs $[20,21]$. Therefore, NF- $\kappa$ B functions as an upstream regulator of IAPs and negatively regulates TRAIL signaling. The role of NF- $\kappa \mathrm{B}$ in the anti-apoptotic process has been studied in prostate cancer cells both in vitro and in vivo. In prostate cancer cell lines, there seems to be an inverse correlation between androgen receptor (AR) status and con- stitutive NF- $\kappa B$ activity [22]. Thus it is tempting to speculate that the constitutive activation of NF- $\kappa \mathrm{B}$ may contribute to prostate cancer cell survival and treatment resistance following androgen ablation [22].

Smac functions as an endogenous IAP-antagonist [23]. Upon stimulation by TRAIL, Smac is released from mitochondria into the cytosol [24]. The released Smac interacts with XIAP through the N-terminal four conserved amino acid residues (AVPI) that bind to the baculoviral IAP repeat 3 (BIR3) domain of XIAP and eliminates the inhibitory effect of XIAP on caspase activation [25-27]. Due to the impressive pro-apoptotic role of Smac, synthetic small molecule Smac-mimicking compounds (Smac-mimetics) are being developed to sensitize apoptosis-resistant cancer cells to various apoptotic stimuli $[3,28]$. Smac-mimetic IAP-antagonists induce TNF $\alpha$-dependent apoptosis in several transformed cell lines [29-31], and small molecule Smac-mimetics successfully sensitize TRAIL-induced apoptosis by blocking functions of IAPs in multiple cancer cells $[11,16,32,33]$. These studies provide a solid foundation for our assertion that mimicking Smac may represent a promising strategy for restoring defective apoptosis signaling triggered by TRAIL in prostate cancer therapy.

Based on the high-resolution experimental 3D structure of Smac in complex with the XIAP BIR3 domain, a group of potent non-peptidic Smac-mimetics, called SH-compounds, were designed that mimic the tetra-peptide at the $\mathrm{N}$-terminal of the Smac protein $[34,35]$. These cell-permeable compounds show at least 20 -fold more potential than the natural Smac peptide to bind to the XIAP BIR3 domain in a cell-free system [34-36]. In the current study, we evaluated the sensitizing potential of one of these compounds, SH122, on TRAIL-mediated cell death in several human prostate cancer cell lines. We also investigated potential molecular targets and the mechanism of action involved in SH122-mediated TRAIL sensitization.

\section{Methods \\ Cell Culture and Reagents}

Human prostate cancer DU145 and LNCaP cells were obtained from the American Type Culture Collection (Manassas, VA). Androgen-independent prostate cancer cell line CL1 derived from its androgen-dependent cell line LNCaP was kindly provided by Dr. Arie Belldegrun (University of California, Los Angeles). Cells were routinely maintained in Dulbecco's Modified Eagle Medium (DMEM, Gibco) with 10\% fetal bovine serum (FBS) and $2 \mathrm{mM}$ L-glutamine. Cultures were maintained in a humidified incubator at $37^{\circ} \mathrm{C}$ with $5 \% \mathrm{CO}_{2}$. Small molecule Smac-mimetic SH122 as well as its inactive analogs SH123 and SH110 were kindly provided by Dr. Shaomeng Wang, University of Michigan. TRAIL was pur- 
chased from Cell Sciences (Canton, MA). Antibodies against XIAP and cIAP-1 were purchased from BD Biosciences (San Jose, CA). Antibodies against PARP, RelA and IкB $\alpha$ were purchased from Santa Cruz Biotechnology (Santa Cruz, CA). Other antibodies include: anti-caspase3 (BioVision, Mountain View, CA), anti-caspase-8 (Calbiochem, San Diego, CA), anti-caspase-9 (Novus Biologicals, Littleton, CO), anti-Bid (Cell Signaling Technology, Beverly, MA), and anti- $\beta$-actin (Sigma, MO). Chemicals were from Sigma unless otherwise indicated.

\section{Cytotoxicity Assay}

To detect the survival of cells after treatment, a standard cell growth assay was performed using the CCK-8 detection kit (Dojindo Molecular Technologies, Gaithersburg, $\mathrm{MD}$ ) following the manufacturer's instructions. Absorbance was detected at $450 \mathrm{~nm}$ and $650 \mathrm{~nm}$ respectively, using a microplate reader (TECAN ULTRA, Research Triangle Park, NC). Cell viability (\%) was normalized by dividing normalized absorbance of treated samples by that of the untreated control [37]. Inhibitory concentration 50\% $\left(\mathrm{IC}_{50}\right)$ was calculated by GraphPad Prism 5.0 (San Diego, CA).

\section{Pull-down Assay}

Cells $\left(1.0 \times 10^{7}\right)$ were disrupted in a lysis buffer $(50 \mathrm{mM}$ Tris-HCl, pH 7.5, $150 \mathrm{mM} \mathrm{NaCl}, 1 \%$ Nonidet P-40, 0.5\% sodium deoxycholate), with freshly added protease inhibitor cocktail (Roche). Cell lysates were homogenized by passing through a $27-1 / 2 \mathrm{G}$ syringe needle (BD). After centrifugation at $10,000 \times \mathrm{g}$ for $15 \mathrm{~min}$ at $4^{\circ} \mathrm{C}$, the supernatant was harvested and incubated with biotin-labeled Smac-mimetic compounds with or without non-labeled compounds, for 1 hour at $4{ }^{\circ} \mathrm{C}$. Lysates were incubated with pre-cleared Streptavidin-Agarose beads (Invitrogen) by gently rotating for 2 hours at $4^{\circ} \mathrm{C}$. The beads were collected and washed with washing buffer (Roche) and eluted in $60 \mu \mathrm{l}$ of loading buffer (Bio-Rad, Hercules, CA). After boiling for $5 \mathrm{~min}$, the eluents were analyzed by immunoblotting to detect proteins that interacted with the compounds [38].

\section{Apoptosis Assay}

For apoptosis analysis by flow cytometry, DU145 cells were treated with SH122 and TRAIL, alone or in combination, with SH110 used as a negative control. Cells were harvested by trypsinization and washed twice with icecold PBS. After centrifuge, cells were stained with $100 \mu \mathrm{l}$ Annexin V-FITC diluted in binding buffer $(10 \mathrm{mM}$ HEPES, $100 \mathrm{mM} \mathrm{NaCl}, 10 \mathrm{mM} \mathrm{KCl}, 1 \mathrm{mM} \mathrm{MgCl}{ }_{2}, 1.8 \mathrm{mM}$ $\mathrm{CaCl}_{2}$ ) containing propidium iodide $(50 \mu \mathrm{g} / \mathrm{ml})$. Cells were incubated for $15 \mathrm{~min}$ at room temperature before analysis by flow cytometry with FACScan (BD) using a 488-nm laser line. Data were analyzed using WinMDI 2.8 software (Purdue University Cytometry Laboratories) as described previously [38].

\section{shRNA Transfection}

The shRNA specific for XIAP in plasmid pRS-shXIAP29 was purchased from OriGene (Rockville, MD). The shRNA specific for cIAP-1 in plasmid pGB-shcIAP-1 was purchased from BioVision (Mountain View, CA). shRNA plasmids $(2.0 \mu \mathrm{g})$ were transfected into DU145 cells using LipofectAMINE 2000 (Invitrogen, Carlsbad, CA), following the manufacturer's instructions. Forty-eight hours after transfection, cells were treated with Smac-mimetic compounds and/or TRAIL and processed for cytotoxicity analysis. Knockdown effect was detected by Western blot.

\section{Western Blot Analysis}

Whole cell proteins were isolated by RIPA buffer $(50 \mathrm{mM}$ Tris-HCl, pH 8.0, $150 \mathrm{mM} \mathrm{NaCl}, 0.1 \%$ SDS, 1\% NP-40, $0.25 \%$ Sodium deoxycholate and $1 \mathrm{mM}$ EDTA) with freshly added protease inhibitor cocktail (Roche). Whole cell lysates were clarified by centrifugation at $10,000 \times \mathrm{g}$ for 10 minutes at $4{ }^{\circ} \mathrm{C}$. Total protein concentrations were determined by BCA Protein Assay (Pierce, Rockford, IL). Equal amounts of proteins were loaded to pre-cast 4-20\% SDS-PAGE gels (Invitrogen). Proteins resolved on gels were transferred to PVDF membranes (Bio-Rad). After electro-transfer, membranes were blocked with $5 \%$ nonfat milk in TBS-T buffer (20 mM Tris-HCl, pH 8.0, $150 \mathrm{mM}$ $\mathrm{NaCl}, 0.05 \%$ Tween 20 ), and probed with the desired primary antibodies. Blots were then incubated with horseradish-conjugated secondary antibodies and detected with the SuperSignal West Pico chemiluminescence substrate (Pierce), and exposed to an X-ray film (Kodak, Rochester, NY). Intensity of the desired bands was analyzed using TotalLab software (Nonlinear Dynamics, Durham, NC).

\section{Cytosol and Nuclei Fractionation}

To detect subcellular redistribution of NF- $\mathrm{BB}$ proteins, cytoplasmic and nuclear fractions were prepared according to the method reported [39] with modifications. Briefly, treated cells $\left(5 \times 10^{6}\right.$ cells) were resuspended in $200 \mu$ l of hypotonic buffer ( $10 \mathrm{mM}$ HEPES, $5 \mathrm{mM} \mathrm{KCl}, 1.5$ $\mathrm{mM} \mathrm{MgCl}_{2}, 1 \mathrm{mM}$ phenylmethylsulfonyl fluoride (PMSF), $1 \mathrm{mM}$ dithiothreitol (DTT), and protease inhibitors), mixed well, and incubated with constant rotation at $4^{\circ} \mathrm{C}$ for $15 \mathrm{~min}$. Nonidet P-40 $(10 \%)$ was then added to reach a final concentration of $0.5 \%$. Cytosolic extract was cleared by centrifugation at $12,000 \mathrm{rpm}$ for $1 \mathrm{~min}$. The pellets were washed once with hypotonic buffer, and resolved in nucleus extraction buffer (20 mM HEPES, 50 $\mathrm{mM} \mathrm{KCl}, 300 \mathrm{mM} \mathrm{NaCl}, 1 \mathrm{mM}$ PMSF, $1 \mathrm{mM}$ DTT, and protease inhibitors), with constant rotation at $4^{\circ} \mathrm{C}$ for 45 min. Nuclear extracts were harvested after centrifuging for $10 \mathrm{~min}$ at $12,000 \mathrm{rpm}$. Subcellular proteins were quanti- 
fied by BCA assay before being employed to Western blot analysis.

\section{Quantitative Real-time PCR ( $q R T-P C R$ )}

qRT-PCR was performed to determine the NF- $\kappa \mathrm{B}$ target gene expression level [40]. Total RNA was extracted from DU145 cells using TRIzol (Invitrogen). Reverse transcription reaction with $1 \mu \mathrm{g}$ of total RNA in $100 \mu \mathrm{l}$ was carried out following the instructions of the TaqMan Reverse Transcription Kit (Applied Biosystems, Foster City, CA). For quantitative PCR, $1 \mu \mathrm{l}$ of gene primers with SYBR Green (Applied Biosystems) in $20 \mu \mathrm{l}$ of reaction volume was applied [41]. Primers were designed as: TNF, forward, 5'CCAGGGACCTCTCTCTAATCAGC3', reverse, 5'CTCAGCTTGAGGGTTTGCTACAA3'; IL8, forward, 5'CGTGGCTCTCTTGGCAGC3', reverse, 5'TCTTTAGCACTCCTTGGCAAAAC3'; Actin (as an internal control): forward, 5'ATGCAGAAGGAGATCACTGC3', reverse, 5'TCATAGTCCGCCTAGAAGCA3'. BIRC4, forward, 5'AGTGGTAGTCCTGTTTCAGCATCA3', reverse, 5'CCGCACGGTATCTCCTTCA3'. FAM probed ICAM-1 primers were commercially obtained from Applied Biosystems. All reactions with TaqMan PCR Master Mix (Applied Biosystems) were performed on the Mastercycler realplex ${ }^{2} \mathrm{~S}$ (Eppendorf, Westbury, NY). Target gene mRNA levels were normalized to actin mRNA according to the following formula: $\left[2^{\wedge}-\left(\mathrm{C}_{\mathrm{T}}\right.\right.$ target $-\mathrm{C}_{\mathrm{T}}$ Actin $\left.)\right] \times 100 \%$, where CT is the threshold cycle. Fold increase was calculated by dividing the normalized target gene expression of the treated sample by that of the untreated control $[41,42]$.

\section{NF- $\kappa$ B Reporter Assay}

DU145 cells were seeded into a 48 -well plate $24 \mathrm{~h}$ before transfection. For each well, cells were transiently cotrans-

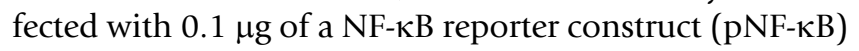
or a control reporter plasmid (pControl) (Panomics Inc., Fremont, CA), together with $0.06 \mu \mathrm{g}$ of $\beta$-galactosidase reporter vector (Promega, Madison, WI), which was used to normalize NF-кB reporter gene activity, using LipofectAMINE 2000 (Invitrogen). Twenty-four hours after transfection, cells were treated with TNF-a or TRAIL for 0 $\mathrm{h}, 1 \mathrm{~h}, 2 \mathrm{~h}, 4 \mathrm{~h}$ and $6 \mathrm{~h}$. To determine the effect of SH122 on TRAIL-induced NF- $\kappa B$ activation, cells were pretreated with SH122 or SH123 for $1 \mathrm{~h}$ followed by TRAIL stimulation for $4 \mathrm{~h}$. Cell lysates were prepared using Reporter Lysis Buffer (Promega). For luciferase and $\beta$-galactosidase assays, the samples were measured on a microplate luminometer using the Bright-Glo luciferase assay kit and $\beta$ galactosidase enzyme assay kit (Promega), respectively, according to the manufacturer's instructions. Fold of activation was calculated for each treated sample by dividing normalized luciferase activity with that of the untreated control.

\section{Statistical Analysis}

Two-tailed Student's $t$-test was employed, using GraphPad Prism 5.0 software (San Diego, CA). A threshold of $P<$ 0.05 was defined as statistically significant.

\section{Results \\ Validation of interactions between Smac-mimetic compound SHI22 and IAPs}

Based on 3-D rational design and computational modeling, SH122 (Figure 1A) was synthesized and developed as a non-peptide small molecule IAP-antagonist that is 20 30-fold more potent than the N-terminal tetrapeptide

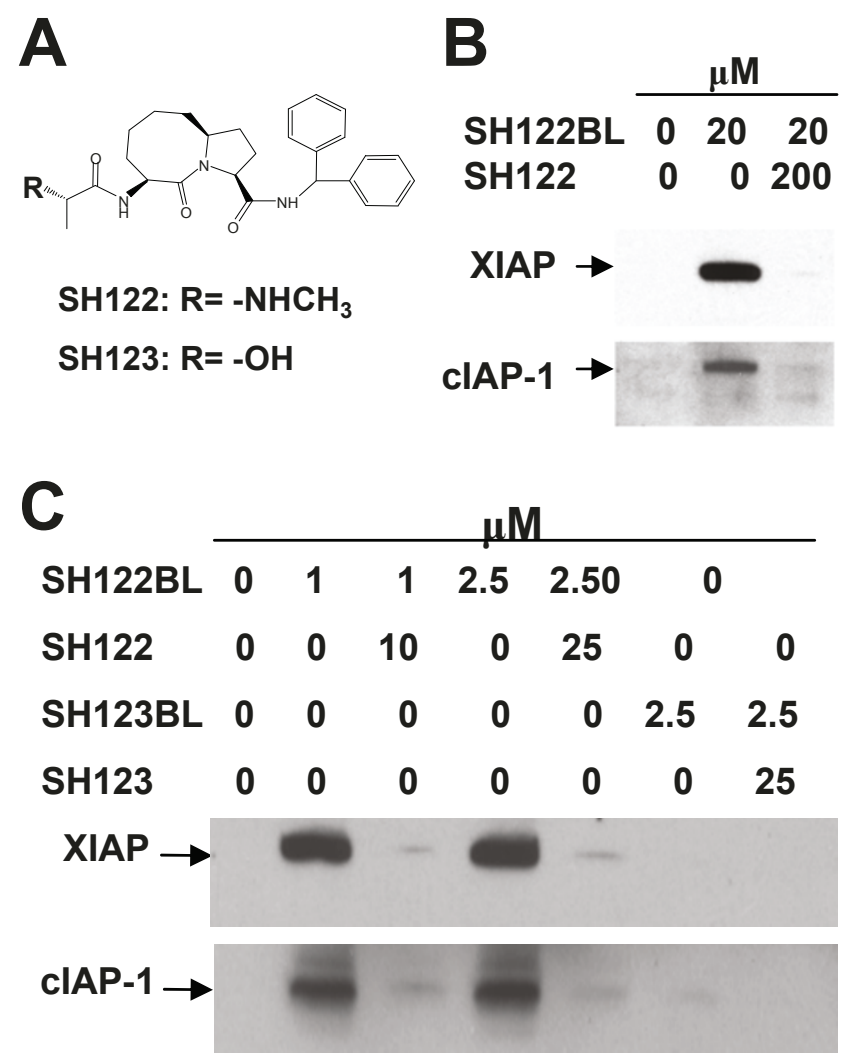

Figure I

Smac-mimetic compound interacted with XIAP and cIAP-I in human prostate cancer cells. A. Structure of the Smac-mimetic compound SHI22, and its inactive control compounds SHI23 and SHIIO. B. Pull-down assay. Biotinlabeled SHI22 (SHI22BL, $20 \mu$ M) was incubated with whole cell lysates of DUI 45 cells with or without 10 -fold excess of non-labeled SHI22, followed by incubation with precleared Streptavidin agarose beads. Eluted beads were employed to Western blot analysis with anti-XIAP or cIAP-I antibody. Data shown represent one of at least three independent experiments. SHI22BL, Biotin-labeled SHI22. C. CLI cell lysate was incubated with $\mathrm{I} \mu \mathrm{M}$ and $2.5 \mu \mathrm{M}$ of SHI22BL, or $2.5 \mu \mathrm{M}$ of SH-I23BL, with or without I0-fold excess of their unlabeled forms. SHI23BL, Biotin-labeled SHI 23. 
of Smac in binding to IAPs, while inactive analogs SH123 and SH110 were shown to be 200-fold less potent [35]. To verify the specific binding of SH122 to IAPs, we employed a pull-down assay with biotin-labeled SH122 (SH122BL) in human prostate cancer cells. As shown in Figure 1B, both XIAP and cIAP-1 were pulled down by SH122 in DU145 cells. Furthermore, pre-incubation with a 10-fold excess of non-biotin-labeled SH122 resulted in a more than $90 \%$ block of the binding of SH122BL to XIAP/CIAP1 , suggesting that the binding was specific. In another androgen-independent prostate cancer CL1 cell line, $1 \mu \mathrm{M}$ of SH122 was sufficient to pull down both XIAP and cIAP1 (Figure 1C), and as with DU145, the binding effect was blocked by a 10-fold excess of non-labeled SH122. By contrast, the negative control compound SH123BL showed almost no binding to either XIAP or CIAP-1, as evidenced in the previous report [38]. These results demonstrate that Smac-mimetic SH122 potently and specifically interacts with XIAP and cIAP-1 in human prostate cancer cells.

\section{SHI 22 sensitizes TRAIL-induced prostate cancer cell growth inhibition}

To detect the combination effects of a Smac-mimetic and TRAIL, cytotoxicity was tested after concurrent treatment with TRAIL and SH122. In DU145 cells, while TRAIL alone had a minor effect on decreasing cell viability, $5 \mu \mathrm{M}$ and $10 \mu \mathrm{M}$ of SH122 showed a 100- and 600-fold sensitization, respectively, compared to TRAIL alone (Figure 2A). By contrast, the negative control compound SH110 produced no sensitization. Similar results were observed in two other prostate cancer cell lines. As shown in Figure 2B, SH122, but not SH110, potentiated TRAIL-induced cell growth inhibition in LNCaP cells. In CL1 cells that were derived from LNCaP, SH122 showed dose-dependent effects on TRAIL sensitization, although the concentration used was approximately 10 -fold less than that for LNCaP cells (Figure 2C). Notably, CL1 seemed to be more sensitive to TRAIL compared with LNCaP, as shown by $\mathrm{IC}_{50}$, suggesting that ablation of the androgen-receptor may result in upregulation of TRAIL receptor expression. These data demonstrate that the Smac-mimetic compound SH122 potentiates TRAIL-mediated cytotoxicity in both TRAIL-resistant and TRAIL-sensitive prostate cancer cell lines.

\section{SHI22 enhances TRAIL-induced apoptosis}

To determine whether apoptosis was involved in TRAILinduced cell death, we examined apoptosis induced by TRAIL in combination with SH122, with Annexin V-FITC and PI staining by flow cytometry analysis. As shown in Figure 3, SH122 increased TRAIL-induced apoptosis in a dose-dependent manner. Even at a lower concentration $(2.5 \mu \mathrm{M})$, SH122 enhanced TRAIL-induced total apoptosis as compared with TRAIL and SH122 alone (Figure 3).
In contrast, TRAIL alone $(50 \mathrm{ng} / \mathrm{ml})$ moderately induced apoptosis, and SH122 alone showed a minor effect on apoptosis, with a slightly increased apoptotic cell population compared with the control even at the highest concentration (Figure 3).

\section{Both death receptor and mitochondrial pathways are involved in SHI22-sensitized, TRAIL-induced apoptosis}

Based on TRAIL-induced apoptotic signaling, we examined the expression of caspases treated with SH122 and TRAIL. Caspase- 8 was cleaved into fragments (p43/41 and p18) as early as $4 \mathrm{~h}$ after exposure to TRAIL alone, while cleavage of caspase- 8 became more intense with increased concentrations of SH122, especially at $6 \mathrm{~h}$ after treatment (Figure 4A). A similar tendency was observed for caspase3. Activation of caspase-3 was further confirmed by poly(ADP-Ribose) polymerase (PARP) cleavage, a typical feature of caspase-dependent apoptosis. PARP was cleaved by TRAIL alone at $4 \mathrm{~h}$ (Figure $4 \mathrm{~A}$ ), while in combination with SH122, cleaved PARP survived up to $8 \mathrm{~h}$. These results suggest that SH122 enhances TRAIL-induced apoptosis by activating caspases and promoting PARP cleavage.

To determine the combination effect of TRAIL and SH122 on the mitochondrial pathway, caspase- 9 and Bid activation were examined. As shown in Figure 4B, Bid levels did not change at $4 \mathrm{~h}$ or $6 \mathrm{~h}$, while at $8 \mathrm{~h}$, Bid levels decreased after combination treatment, but not from treatment by TRAIL alone. Furthermore, caspase- 9 cleavage could be detected as early as $4 \mathrm{~h}$ by either TRAIL alone or in combination with SH122, as evidenced by the appearance of its cleaved forms, p35 and p17. Interestingly, both pro- and cleaved caspase- 9 were diminished at $8 \mathrm{~h}$, indicating that caspase-9 activation was an early event with Bid cleavage (Figure 4B). These data suggest that the mitochondria pathway is also involved in TRAIL-induced, SH122-mediated apoptosis. Taken together, these in vitro apoptosis data reveal that SH122 potentiates TRAIL-induced apoptosis by activating both the extrinsic death receptor pathway and the intrinsic mitochondrial pathway, typically through activation of the caspase cascade. More importantly, SH-122 combined with TRAIL induced a longerlasting apoptosis than TRAIL alone ( $8 \mathrm{~h} v$ s. $4 \mathrm{~h}$ ), showing that SH-122 enhanced the effect of TRAIL treatment.

\section{Downregulation of XIAP and CIAP-I sensitizes TRAIL- induced cell death}

It is well established that IAPs (especially XIAP) are responsible for blocking TRAIL-induced apoptosis by inhibiting caspase functions $[11,14,43]$. To investigate the potential link between IAPs and TRAIL-resistance, shorthairpin RNA (shRNA) of XIAP or cIAP-1 was transfected into DU145 cells, and cytotoxicity was examined. As shown in Figure 5, XIAP or CIAP-1 knockdown shifted the 
A

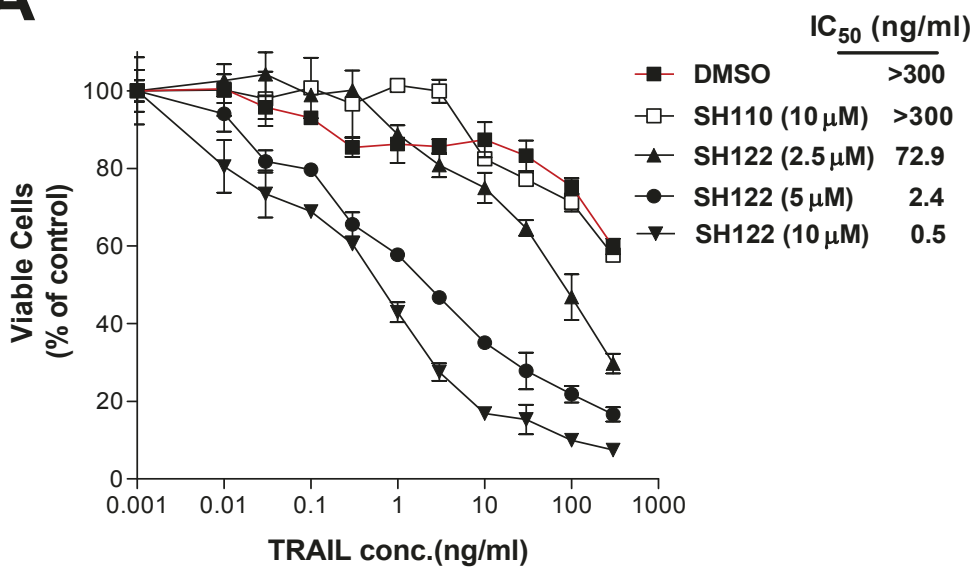

B
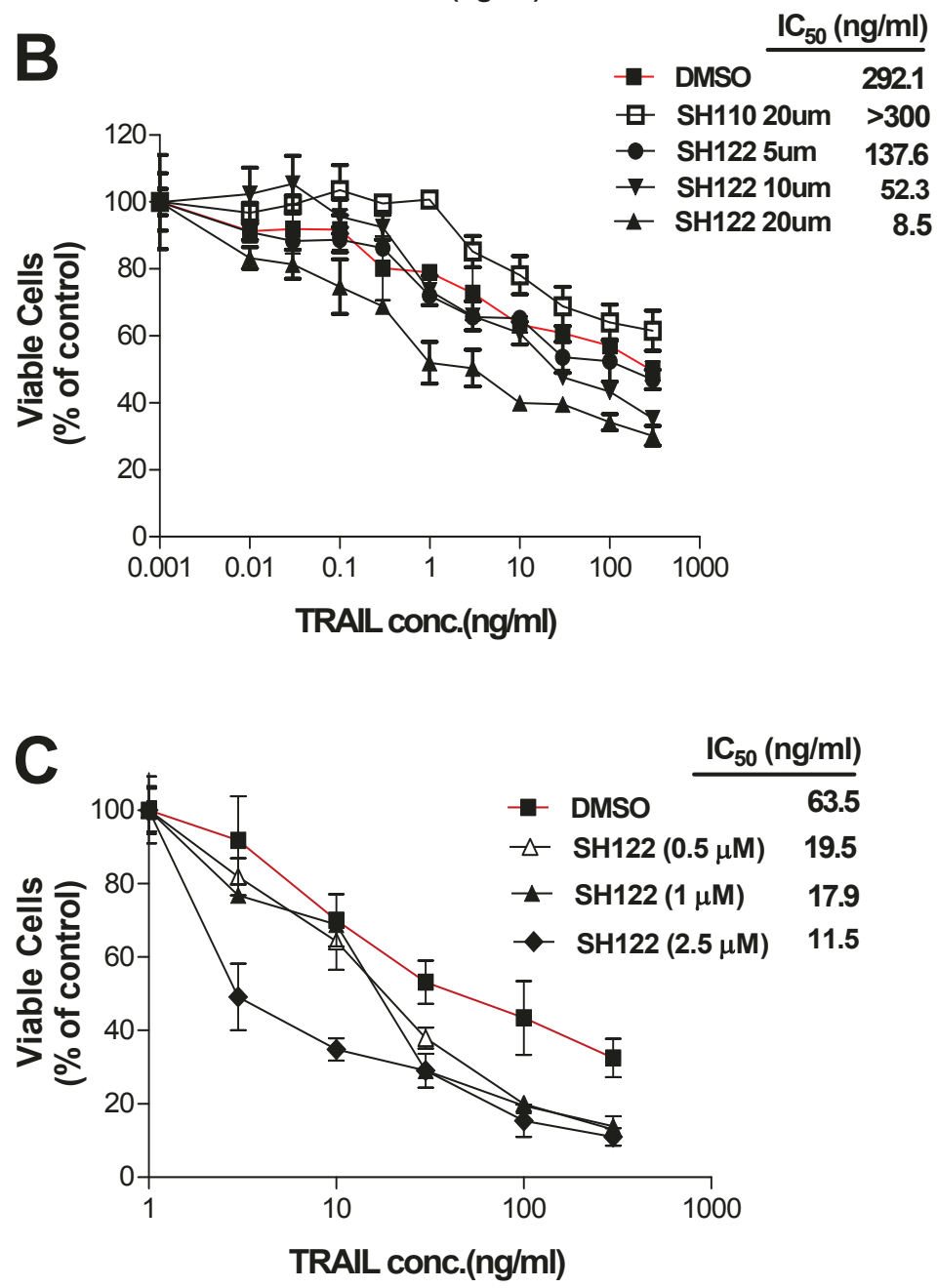

Figure 2

SHI 22 promoted TRAIL-induced cell death in prostate cancer cell line DUI 45 (A), LNCaP (B) and CLI (C). Cells (5,000 cells/well in 96-well plates) were treated with different concentrations of TRAIL and SHI22, alone or in combination, with SHIIO as a negative control. After incubation for 96 h, cells were stained with Cell Counting kit-8 reagent. The optical density of each sample was measured. Data were normalized as described in Materials and Methods. Data were presented as mean \pm SD $(n=3)$. 


\section{SH122}

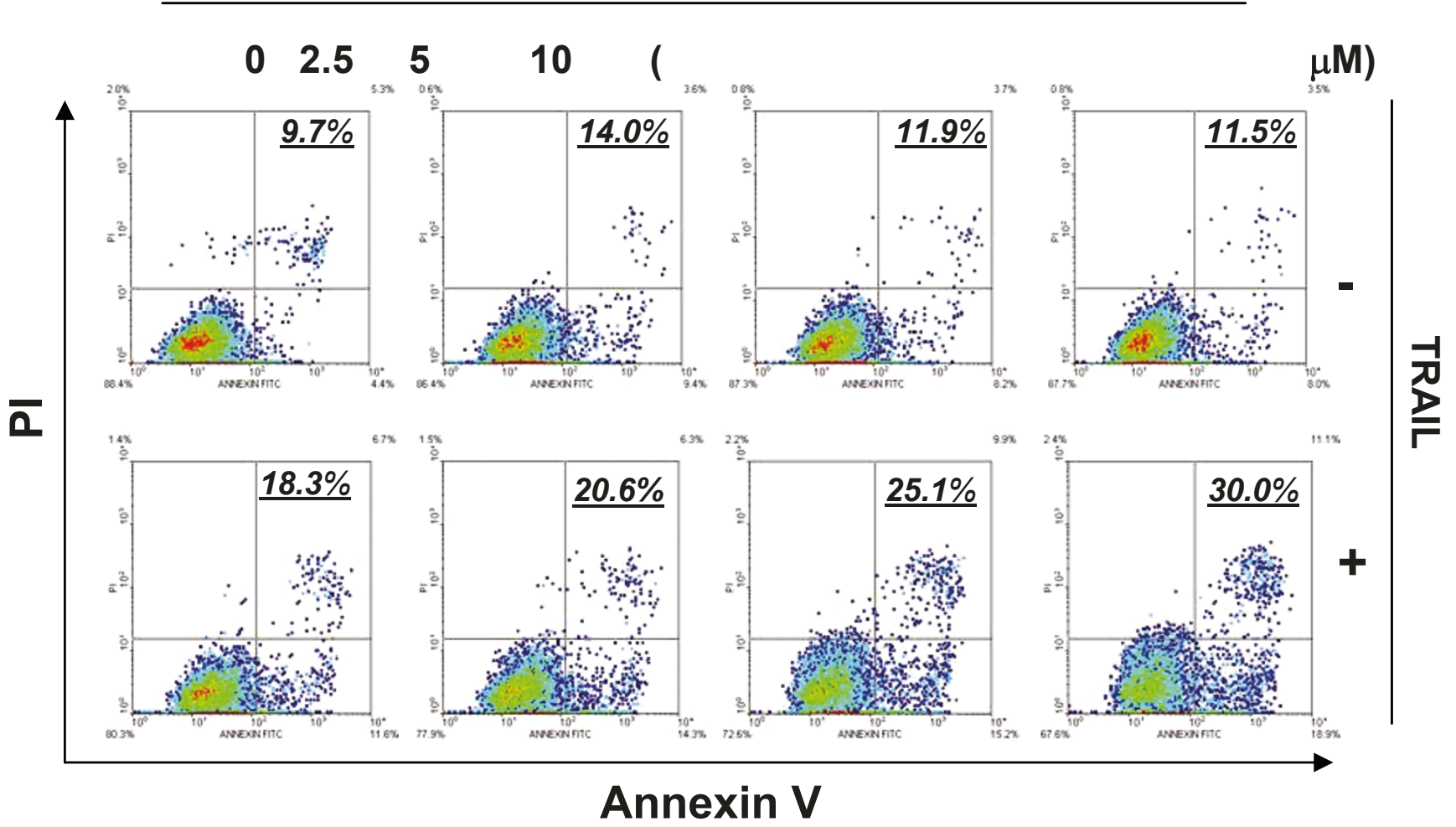

Figure 3

SHI 22 enhanced TRAIL-induced apoptosis. DUI45 cells were seeded into 6 -well plates at a concentration of $2 \times 105 / \mathrm{ml}$, and exposed by $2.5,5$ and $10 \mu \mathrm{M}$ of SHI22, with or without TRAIL (50 ng/ml). Eighteen hours after incubation, cells were harvested and processed for Annexin V-FITC and PI staining by flow cytometry. Numbers represented total apoptosis (Annexin $\mathrm{V}$ positive cell population). Data represented one of three independent experiments.

cytotoxicity curve to the left, i.e., sensitized the cells to TRAIL. Based on $\mathrm{IC}_{50}$, a more than 300-fold sensitization was observed in the cells transfected with XIAP shRNA as compared with the vector control (Figure 5A and 5B). Similarly, in cIAP-1-shRNA transfected cells, an approximately 100-fold sensitization was achieved as compared with that of the vector control (Figure 5C and 5D). These results demonstrate that knockdown of XIAP and cIAP-1 effectively sensitizes the cells to TRAIL, indicating that both XIAP and cIAP-1 are involved in TRAIL-resistance, and that silencing XIAP and/or c-IAP1 can overcome such resistance in prostate cancer cells.

\section{Downregulation of XIAP attenuates sensitization potential of SHI 22 on TRAIL-induced cell death}

Earlier studies have shown that both XIAP and CIAP-1 are specific targets of SH122 (Figure 1B and 1C), and knockdown of XIAP/cIAP-1 resulted in significant TRAIL-sensitization (Figure 5). To evaluate the role of XIAP in SH122mediated TRAIL sensitization, we treated XIAP knockdown cells with SH122 and TRAIL. In vector shRNA
(shControl)-transfected cells, negative compound SH110 showed a moderate sensitizing effect, while SH122 dramatically synergized TRAIL-induced cell death in a dosedependent manner. Even at the lowest concentration (0.1 $\mu \mathrm{M})$, SH122 was 22-fold more potent in sensitizing TRAIL than a high concentration of SH110 (10 $\mu \mathrm{M})$ (Figure 6A). However, in XIAP shRNA-transfected cells, the sensitizing potential of SH122 was $10^{2} \sim 10^{4}$-fold less potent than shown by the shControl cells (Figure 6B). These results demonstrate that silencing XIAP dramatically attenuates SH122-mediated sensitization of TRAIL-induced cytotoxicity, suggesting that XIAP is an important target of IAPinhibitors involved in TRAIL sensitization.

\section{SHI 22 inhibits TRAIL-induced NF- $\kappa B$ activation}

Because NF- $\kappa$ B activation is known to play a crucial role in inhibiting apoptosis $[19,21]$, we thought it was important to evaluate the effect of SH122 on NF- $\kappa \mathrm{B}$ activation induced by TRAIL. First, we treated cells with TRAIL alone at the concentration that achieved apoptosis, to create optimal conditions for NF- $\mathrm{B}$ activation in our system. 


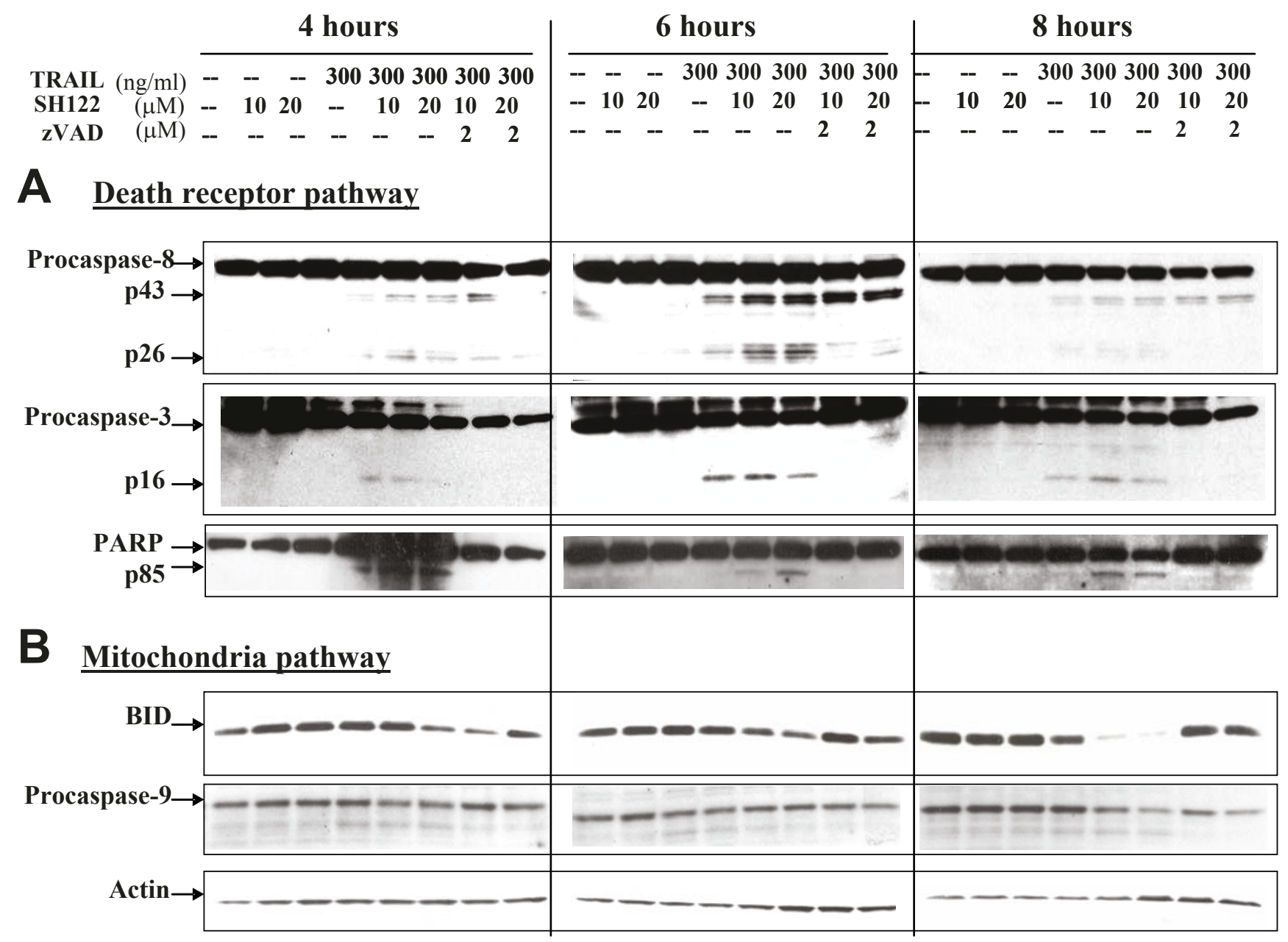

\section{Figure 4}

SHI 22 potentiated TRAIL-induced apoptosis by activating both the death-receptor pathway (A) and mitochondrial pathway (B). DUI45 cells were treated with 10 and $20 \mu \mathrm{M}$ of SHI22, in the presence or absence of $300 \mathrm{ng} / \mathrm{ml}$ of TRAIL, with or without pretreatment with zVAD $(2 \mu \mathrm{M})$, for 4,6 , and $8 \mathrm{~h}$, respectively. Whole cell lysates (30 $\mu \mathrm{g})$ were subjected to Western blot analysis. Membranes were probed with antibodies against caspase-8, caspase-3, caspase-9, PARP and Bid. Actin was shown as a loading control.

TRAIL induced I $\kappa \mathrm{B} \alpha$ degradation by $60 \%$ at 40 min posttreatment, and concomitantly, nuclear RelA expression increased over 3 -fold at $40 \mathrm{~min}$ and lasted for $3 \mathrm{~h}$ of treatment (Figure 7A). This revealed that TRAIL induced NF- $\kappa B$ activation via the classic pathway by degrading cytosolic $\mathrm{I} \kappa \mathrm{B} \alpha$ and promoting RelA nuclear translocation. It is worth noting that at $120 \mathrm{~min}$ post treatment, cleaved PARP was observed in the nuclei extracts, suggesting a quick apoptosis induced by TRAIL along with NF- $\kappa$ B activation, also reflecting a balance of cell death and cell survival triggered by the same stimuli (Figure 7A). TRAIL consistently induced multiple NF- $\mathrm{KB}$ target genes expression. For the four target genes examined, TNF and IL8 expression reached their peak at $2 \mathrm{~h}$ post treatment, while ICAM-1 and BIRC4 expression continued to increase during treatment (Figure 7B).

Next, we pretreated DU145 cells with varying concentrations of SH122 or SH123 to evaluate the effect of the IAPantagonist on TRAIL-induced NF- $\kappa \mathrm{B}$ activation. Pre-treatment of SH122 potently suppressed I $\kappa \mathrm{B} \alpha$ degradation and RelA translocation in a dose-dependent manner (Figure $7 \mathrm{C}$ ). At the same time point, SH122 was consistently shown to suppress expression of all three NF- $\kappa \mathrm{B}$ target genes by $30-80 \%(P<0.01$ vs. control) even at a lower concentration (Figure 7D). In comparison, even high con- 

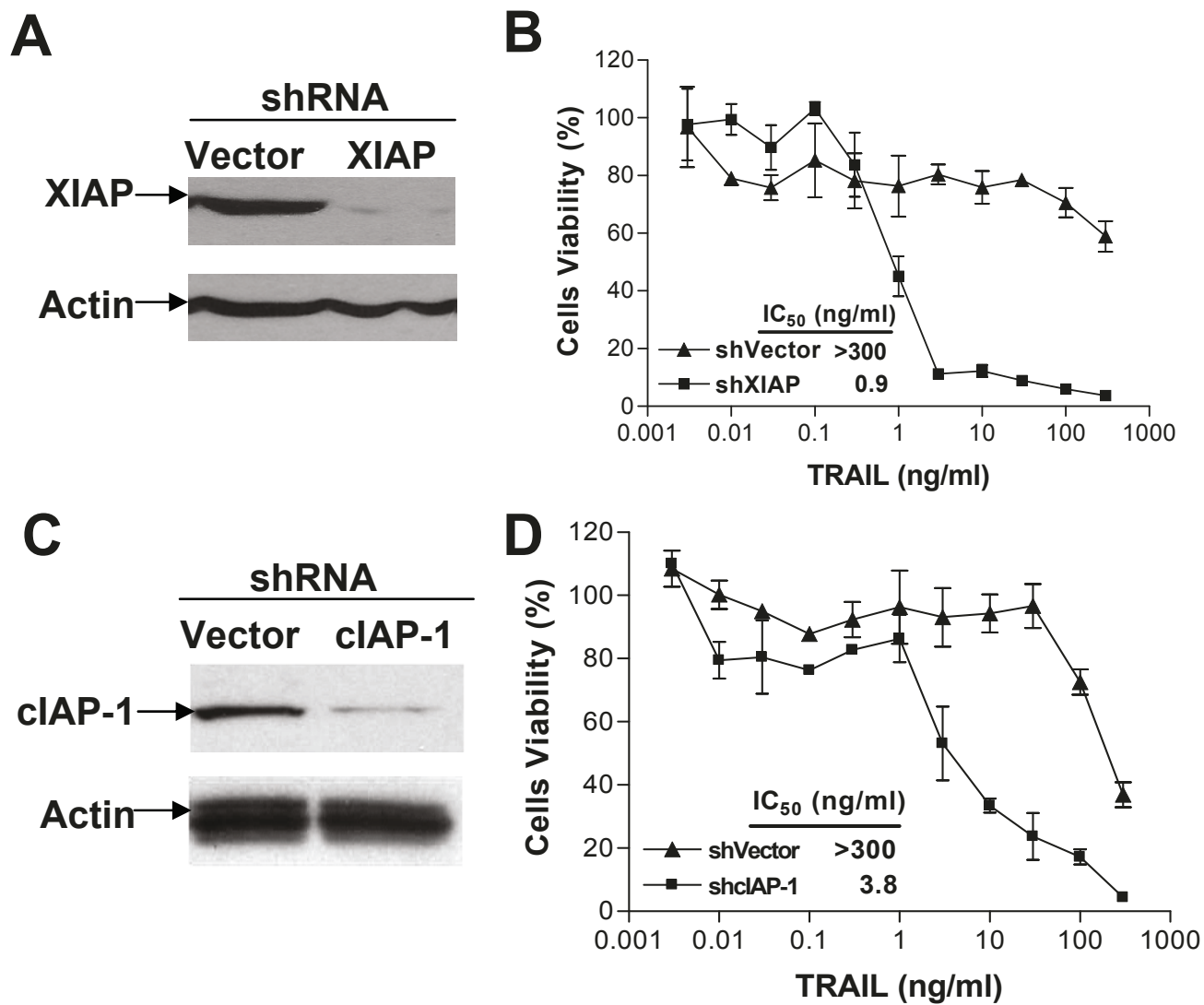

\section{Figure 5}

Downregulation of XIAP or cIAP-I sensitized TRAIL-induced cell death. DUI45 cells were transfected with shRNA of XIAP (shXIAP) (A, B) or cIAP-I (shclAP-I) (C, D), or the vector control (shVector), and knockdown effect was measured $48 \mathrm{~h}$ after transfection $(\mathbf{A}, \mathbf{C})$. Transfected cells were treated with TRAIL, and cytotoxicity was determined by CCK-8 detection kit (B, D). Normalized data were presented as mean \pm SD $(n=3)$.

centrations of the negative compound SH123 altered neither NF- $\mathrm{B}$ protein redistribution (Figure $7 \mathrm{C}$ ) nor $\mathrm{NF}-\kappa \mathrm{B}$ target genes expression (Figure 7D).

To further validate that SH-122 inhibits NF- $\kappa$ B pathway, we analyzed the effects of SH122 on NF- $\kappa$ B activation induced by TRAIL in DU145 cells using luciferase-based $\mathrm{NF}-\kappa \mathrm{B}$ reporter assay. We first examined the time-course of TRAIL-induced NF- $\kappa \mathrm{B}$ activation by NF- $\kappa \mathrm{B}$ reporter assay. $4 \mathrm{~h}$ TRAIL treatment resulted in $\sim 5$-fold NF- $\kappa \mathrm{B}$ activation, and at $6 \mathrm{~h}$ over 9-fold activation was observed (Figure 7E), but at this time point the cells started to show signs of cell death. Therefore, we selected the $4 \mathrm{~h}$ TRAIL treatment in our NF- $\kappa \mathrm{B}$ reporter assay. As shown in Figure $7 \mathrm{~F}$, SH122 inhibited TRAIL-induced NF- $\kappa \mathrm{B}$ activation by $>60 \%$ at doses of 5 and $10 \mathrm{uM}$, whereas the control compound SH123 had no such effect. Similar results were also observed in DU145 cells stimulated with TNFa (data not shown). These results demonstrate that SH122 exhibits a promising effect of blocking the TRAIL-induced NF- $\kappa B$ activation.

\section{Discussion}

In this study, we found that the small molecule Smacmimetic SH122 potently sensitized TRAIL-induced apoptosis in multiple human prostate cancer cell lines. We also found that although downregulation of either XIAP or cIAP-1 sensitized TRAIL-mediated cytotoxicity, XIAP knockdown attenuated SH122-mediated TRAIL sensitization. Our results demonstrate that IAPs are valid molecular targets for modulating TRAIL sensitivity in prostate cancer cells, and show that blocking IAPs achieves improved efficacy and overcomes resistance to TRAIL. In addition, our results demonstrate that NF- $\mathrm{B}$ is involved in regulating sensitivity of prostate cancer cells to TRAIL, and a Smac-mimetic can augment TRAIL-induced apopto-

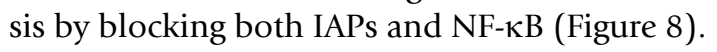


A DU145-shVector
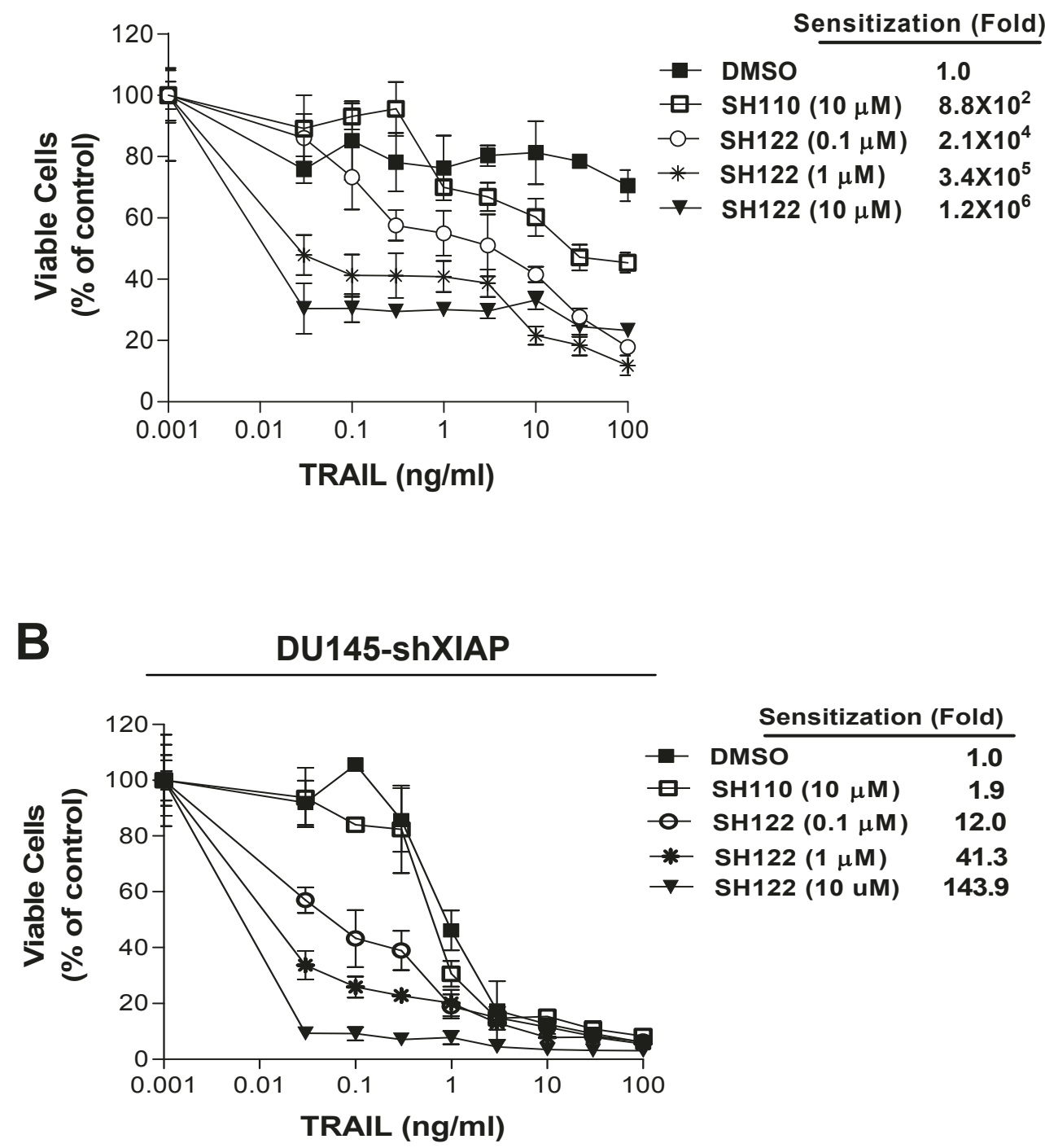

Figure 6

Downregulation of XIAP attenuated sensitization effect of SHI 22 on TRAIL-induced cell death. Cells transfected with either XIAP shRNA (A) or the vector control shRNA (B) were treated with serial diluted TRAIL, alone or in combination with 0.1 , I and I0 $\mu \mathrm{M}$ of SHI22, respectively, with $10 \mu \mathrm{M}$ of SHIIO as a negative control. Cytotoxicity was determined by CCK-8 detection kit. Normalized data were presented as mean \pm SD $(n=3)$. Fold of sensitization was calculated by dividing $\mathrm{IC}_{50}$ of the compound-treated group by that of DMSO control. 

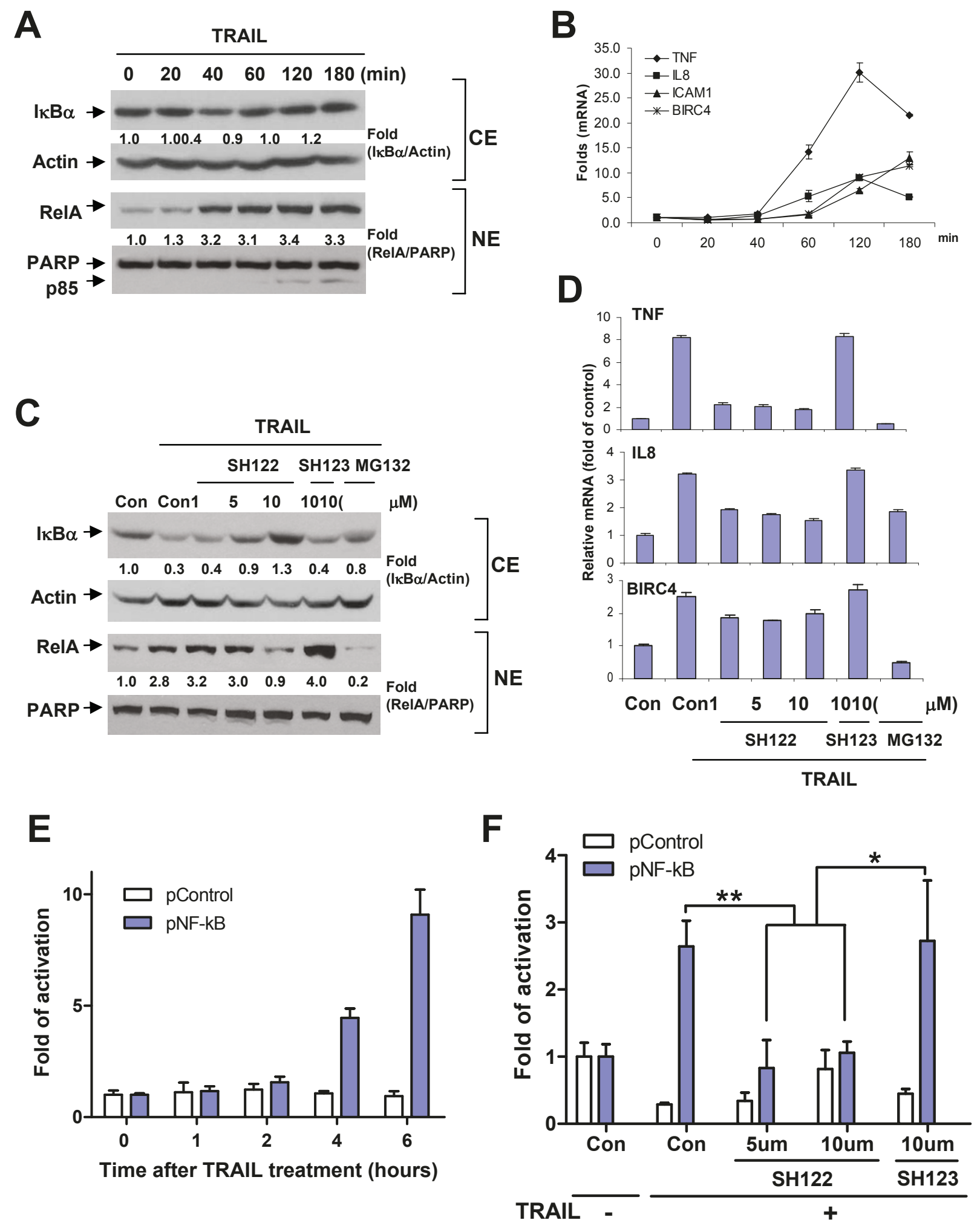

Figure 7 (see legend on next page) 
Figure 7 (see previous page)

SHI 22 suppressed TRAIL-induced NF- $\kappa$ B activation. A. DUI 45 cells were treated with $300 \mathrm{ng} / \mathrm{ml}$ of TRAIL for the indicated time. Cytosol and nuclei subcompartments were fractionated for detection of IKB $\alpha$ and RelA, with Actin and PARP used as markers of cytosolic and nuclear extracts, respectively. Relative expression of $1 \kappa B \alpha$ and RelA was shown by dividing band intensity by that of Actin and PARP, respectively. CE, cytosolic extract; NE, nuclear extract. B. After treatment with 300 $\mathrm{ng} / \mathrm{ml}$ of TRAIL, cells were harvested for quantitative RT-PCR detect NF- $\kappa \mathrm{B}$ target genes. Fold increase of gene expression was calculated by dividing the normalized gene expression activity by that of the untreated control. C. Cells were pre-treated with desired compounds for I h, and challenged with TRAIL $(300 \mathrm{ng} / \mathrm{ml})$ for $40 \mathrm{~min}$. Cytosol and nuclei subcellular compartments were fractionated for detection of $I \kappa B \alpha$ and RelA, respectively. MGI 32 was used as a positive control for blocking NF- $\kappa B$. D. After treatment as described in $\mathbf{C}$, cells were harvested for quantitative RT-PCR to detect three NF- $\kappa B$ target genes. $\mathbf{E}$, Timecourse of TRAIL-induced NF- $\kappa B$ activation examined by NF- $\kappa B$ luciferase reporter assay. DUI 45 cells were transiently cotransfected with $\mathrm{pNF}-\kappa \mathrm{B}$ or $\mathrm{pControl}$ together with $\beta$-galactosidase plasmid, and then treated with TRAIL for the indicated time. Luciferase and $\beta$-galactosidase activities were measured as described in Materials and Methods. F, SHI 22 inhibited TRAILinduced NF- $\kappa$ B activation in NF- $\kappa$ B luciferase reporter assay. Transfected DUI45 cells were pretreated with SHI 22 or SHI 23 for I $\mathrm{h}$ followed by TRAIL treatment for $4 \mathrm{~h}$. Fold of NF- $\mathrm{kB}$ activation was calculated by dividing the normalized luciferase activity by that of the untreated control. Representative results of at least two independent experiments. Columns, mean; bars, SD $(n=3)$. Con, DMSO vehicle control. ** $P<0.01 ; * P<0.05$, Student's t-test $(n=3)$.

Smac-mimetic IAP-antagonists sensitize TRAIL-induced apoptosis by blocking XIAP function in multiple tumor models, including breast cancer [32], multiple myeloma [16], glioblastoma [11] and ovarian cancer [33]. Embelin, a natural XIAP inhibitor [44], sensitized TRAIL-induced apoptosis in pancreatic cancer cells [45]. These findings provide a strong rationale for using Smac-mimetics to achieve TRAIL-sensitization by functional inhibition of the overexpressed XIAP. To our knowledge, only a limited number of studies have reported on the combination of small molecule Smac-mimetic candidates with TRAIL in prostate cancer therapy. Interestingly, in prostate cancer cell lines, no strict correlation has been observed between XIAP expression and TRAIL responsiveness [3]. This discrepancy indicates that XIAP is not the only determinant of TRAIL-resistance in prostate cancer. Nevertheless, blocking XIAP function by transient overexpression of Smac achieved a promising enhanced efficacy in combination with TRAIL in prostate cancer cell lines [46], indicating that XIAP is the predominant target for TRAIL sensitivity. In our system, we found that the IAP-antagonist alone did not induce apoptosis [35], but potently sensitized TRAIL-induced cytotoxicity in TRAIL-resistant DU145 and LNCaP cells, as well as in relatively TRAILsensitive CL1 cells. Our finding, consistent with other reports $[17,47,48]$, suggests that the IAP-antagonist exerts a potent sensitization effect independent of cell responsiveness to TRAIL, and provides an attractive strategy for using IAP-antagonists in combination treatment.

In addition to IAPs, NF- $\kappa \mathrm{B}$ is another well documented pro-survival factor that is involved in mediating resistance to TRAIL-induced apoptosis in tumor cells [49]. It has been reported that constitutively active NF- $\mathrm{KB}$ signaling leads to TRAIL-resistance by upregulating XIAP in multiple human cancer cells [50], and in certain tumor cell types, NF- $\mathrm{KB}$ is the primary cause for TRAIL resistance [10]. Moreover, there is mounting evidence that CIAP-1 physically interacts with adaptor proteins in TNF $\alpha /$ TRAILmediated NF- $\mathrm{KB}$ signaling [51-53], suggesting that IAPs serve as "bridging" molecules between the apoptosis pathway and NF-kB pathway triggered by TRAIL (Figure 8). Thus it is reasonable to postulate that the pro-apoptotic IAP-antagonists may modulate NF- $\mathrm{\kappa B}$. Indeed, several recent studies reveal that Smac-mimetics (IAP-antagonists) can induce TNF $\alpha$-dependent apoptosis in Smacsensitive cell lines by degrading cIAPs and regulating NF$\kappa \mathrm{B}$ signaling [29-31]. These findings indicate that in cell lines that are sensitive to both Smac and TNFa, an IAPantagonist itself is sufficient to induce cell death through autocrine TNF $\alpha$ signaling and caspase-8-dependent apoptosis [31,53].

Apart from these findings, our study shows that Smacmimetics as a single agent induce neither cell death nor $\mathrm{NF}-\kappa \mathrm{B}$ activation in androgen-independent prostate cancer cells, suggesting that both apoptosis and NF- $\mathrm{KB}$ failed to be activated by the Smac-mimetic alone in chemo- or radioresistant cells with constitutively active NF- $\mathrm{KB}$ signaling. The mechanism underlying such a discrepancy in different cell types remains to be investigated. However, our data provide the first evidence that a potent Smac-mimetic IAP-antagonist directly blocks TRAIL-induced NF- $\mathrm{BB}$ activation in prostate cancer cells. In fact, at the concentration that effectively suppressed NF- $\mathrm{KB}$ activation, SH122 sensitized the effect of TRAIL several-hundred-fold, suggesting that blocking NF- $\kappa B$ by a Smac-mimetic is sufficient for TRAIL sensitization. Additionally, SH122-mediated inhibition of IKB $\alpha$ degradation reflects an effect at the level of the IкB $\alpha$ kinase (IKK) complex that is in agreement with others' observations in different systems $[11,54]$, indicating activation of the canonical NF- $\mathrm{kB}$ pathway. Further- 


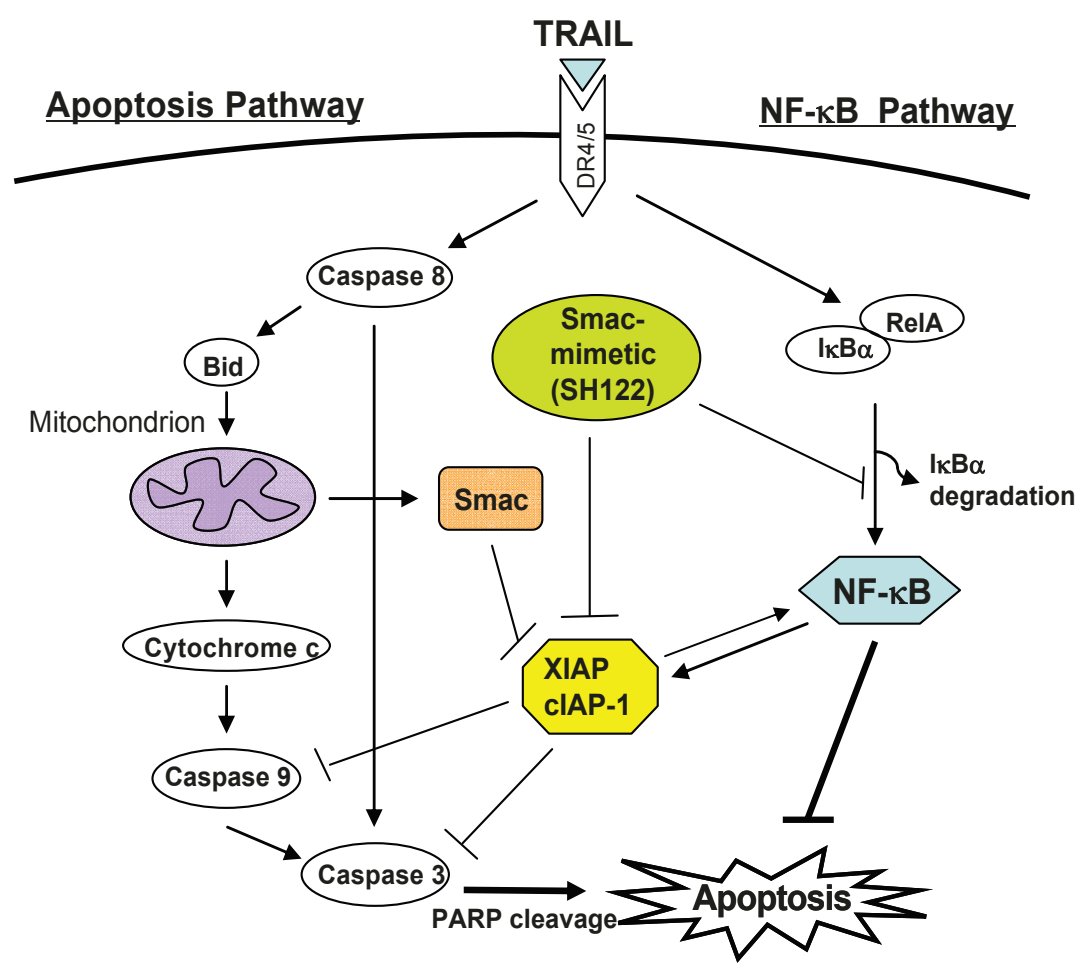

Figure 8

Working model of Smac-mimetic IAP-antagonist sensitizing TRAIL-induced apoptosis by suppressing NF- $\kappa$ B. TRAIL triggers apoptosis via both the death-receptor (DR4/DR5) and mitochondrial pathways, by activating initiator caspase-8 and -9 , and effector caspase-3. Furthermore, both Bid and PARP are cleaved by caspases, which are typical predictors of TRAIL-mediated apoptosis. A Smac-mimetic effectively blocks IAP (XIAP/cIAP-I) function and facilitates caspase activation. Simultaneously, the Smac-mimetic suppresses TRAIL-induced classical NF- $\kappa B$ activation by preventing $I \kappa B \alpha$ degradation and RelA nuclear translocation. Blockade of NF- $\kappa B$ - XIAP signaling by small molecule Smac-mimetic abolishes counteraction of pro-survival factors on TRAIL-mediated apoptosis.

more, SH122 suppresses XIAP mRNA expression driven by NF- $\kappa \mathrm{B}$, demonstrating that TRAIL-mediated sensitization by small molecule Smac-mimetic is associated with functional inhibition of both XIAP and NF- $\kappa$ B, especially in androgen-independent prostate cancer. Future work will focus on evaluating the response to TRAIL and the IAP-antagonists in androgen-dependent (AD) LNCaP cells and their androgen-independent (AI) derivative CL1 cells. This isogenic (for hormone dependence) cell model should permit us to determine if NF- $\kappa$ B plays an essential role in the transition from $\mathrm{AD}$ to $\mathrm{AI}$ prostate cancer and to discover if overcoming resistance to TRAIL-induced apoptosis can be achieved by down-modulating the NF- $\kappa \mathrm{B}$ IAP signaling pathway.

\section{Conclusion}

Resistance to chemo- or radiotherapy, which is often associated with recurrence after prior androgen deprivation therapy in human prostate cancer, remains a severe clinical problem [55]. TRAIL is currently being evaluated in
Phase I/II clinical trials, alone or in combination with other therapies, for the treatment of prostate cancer $[3,10]$. Our study indicates that blockade of IAPs by a small molecule Smac-mimetic promotes TRAIL-induced apoptosis in prostate cancer cells via modulating both the apoptosis pathway and NF- $\kappa$ B pathway. As IAPs are key molecular targets for the development of cancer cell-selective therapeutics, our findings reveal a potential mechanism for a Smac-mimetic IAP-antagonist on TRAILmediated signaling, and suggest that modulating IAPs may contribute to enhanced TRAIL efficacy, especially in androgen-independent prostate cancer with high levels of IAPs and constitutively active NF- $\kappa \mathrm{B}$ signaling. Therefore, small molecule Smac-mimetics that specifically target IAPs may yield a potential therapeutic benefit with TRAILbased therapy in chemo- or radioresistant prostate cancer. 


\section{Competing interests}

LX is a co-inventor of the Smac-mimetic compounds involved in the study. All other authors declare no competing interests.

\section{Authors' contributions}

YD and ML contributed equally to this study. YD participated in the design of the study, performed NF- $\kappa \mathrm{B}$ assay and drafted the manuscript; ML performed the cell culture, MTT assay, apoptosis assay, transfection and Western Blot, WT helped with the Western Blot analysis; YL and JL carried out NF- $\kappa \mathrm{B}$ luciferase reporter assay; TSL participated in the project design and in revising the manuscript; LX supervised the study, experimental design, data analysis, and revision of the manuscript. All authors read and approved the final manuscript.

\section{Acknowledgements}

We thank Dr. Arie Belldegrun at University of California Los Angeles for kindly providing the androgen-independent prostate cancer cell line CLI; Dr. Susan Harris for help with the manuscript; Drs. Shaomeng Wang and Haiying Sun at University of Michigan for providing the Smac-mimetic compounds; and the University of Michigan Comprehensive Cancer Center (UMCCC) Flow Cytometry Core for flow cytometry analysis.

Grant support: This study was supported in part by Department of Defense Prostate Cancer Research Program W8IXWH-06-I-0010 (to L. X.), NIH grants CAI2I830, CAI 28220 and CAI34655 (to L. X.), and by $\mathrm{NIH}$ through the University of Michigan's Cancer Center Support Grant (5 P30 CA46592).

\section{References}

I. DiPaola RS, Patel J, Rafi MM: Targeting apoptosis in prostate cancer. Hematol Oncol Clin North Am 200I, I 5(3):509-524.

2. Xu L, Frederik P, Pirollo KF, Tang WH, Rait A, Xiang LM, Huang W, Cruz I, Yin Y, Chang EH: Self-assembly of a virus-mimicking nanostructure system for efficient tumor-targeted gene delivery. Hum Gene Ther 2002, I3(3):469-48I.

3. Bucur O, Ray S, Bucur MC, Almasan A: APO2 ligand/tumor necrosis factor-related apoptosis-inducing ligand in prostate cancer therapy. Front Biosci 2006, I I: I549-I568.

4. Shankar S, Siddiqui I, Srivastava RK: Molecular mechanisms of resveratrol (3,4,5-trihydroxy-trans-stilbene) and its interaction with TNF-related apoptosis inducing ligand (TRAIL) in androgen-insensitive prostate cancer cells. Mol Cell Biochem 2007, 304( ( -2):273-285.

5. Steele LP, Georgopoulos NT, Southgate J, Selby PJ, Trejdosiewicz LK: Differential susceptibility to TRAIL of normal versus malignant human urothelial cells. Cell Death Differ 2006, I3(9): | $564-1576$.

6. Almasan A, Ashkenazi A: Apo2L/TRAIL: apoptosis signaling, biology, and potential for cancer therapy. Cytokine Growth Factor Rev 2003, | 4(3-4):337-348.

7. $\mathrm{Ng}$ CP, Zisman A, Bonavida B: Synergy is achieved by complementation with Apo2L/TRAIL and actinomycin D in Apo2L/ TRAIL-mediated apoptosis of prostate cancer cells: role of XIAP in resistance. Prostate 2002, 53(4):286-299.

8. Knight MJ, Riffkin CD, Ekert PG, Ashley DM, Hawkins CJ: Caspase8 levels affect necessity for mitochondrial amplification in death ligand-induced glioma cell apoptosis. Mol Carcinog 2004, 39(3): $173-182$.

9. Fulda S, Meyer E, Debatin KM: Inhibition of TRAIL-induced apoptosis by Bcl-2 overexpression. Oncogene 2002, 2 I (I 5):2283-2294.

10. Kruyt FA: TRAIL and cancer therapy. Cancer Lett 2008, 263(I): |4-25.
II. Li L, Thomas RM, Suzuki H, De Brabander JK, Wang X, Harran PG: A small molecule Smac mimic potentiates TRAIL- and TNFalpha-mediated cell death. Science 2004, 305(5689): | 47|- | 474.

12. Cummins JM, Kohli M, Rago C, Kinzler KW, Vogelstein B, Bunz F: Xlinked inhibitor of apoptosis protein (XIAP) is a nonredundant modulator of tumor necrosis factor-related apoptosisinducing ligand (TRAIL)-mediated apoptosis in human cancer cells. Cancer Res 2004, 64(9):3006-3008.

13. Fulda S, Wick W, Weller M, Debatin KM: Smac agonists sensitize for Apo2L/TRAIL- or anticancer drug-induced apoptosis and induce regression of malignant glioma in vivo. Nat Med 2002, 8(8):808-8I5.

14. Schimmer AD, Welsh K, Pinilla C, Wang Z, Krajewska M, Bonneau MJ, Pedersen IM, Kitada S, Scott FL, Bailly-Maitre B, Glinsky G, Scudiero D, Sausville E, Salvesen G, Nefzi A, Ostresh JM, Houghten RA, Reed JC: Small-molecule antagonists of apoptosis suppressor XIAP exhibit broad antitumor activity. Cancer Cell 2004, 5(I):25-35.

15. Gaither A, Porter D, Yao Y, Borawski J, Yang G, Donovan J, Sage D, Slisz J, Tran M, Straub C, Ramsey T, lourgenko V, Huang A, Chen Y, Schlegel R, Labow M, Fawell S, Sellers WR, Zawel L: A Smac mimetic rescue screen reveals roles for inhibitor of apoptosis proteins in tumor necrosis factor-alpha signaling. Cancer Res 2007, 67(24): I |493-I | 498.

16. Chauhan D, Neri P, Velankar M, Podar K, Hideshima T, Fulciniti M, Tassone P, Raje N, Mitsiades C, Mitsiades N, Richardson P, Zawel L, Tran M, Munshi N, Anderson KC: Targeting mitochondrial factor Smac/DIABLO as therapy for multiple myeloma (MM). Blood 2007, I09(3): | 220- 1227.

17. Chawla-Sarkar M, Bae SI, Reu FJ, Jacobs BS, Lindner DJ, Borden EC: Downregulation of Bcl-2, FLIP or IAPs (XIAP and survivin) by siRNAs sensitizes resistant melanoma cells to Apo2L/ TRAIL-induced apoptosis. Cell Death Differ 2004, I I(8):91 5-923.

18. Zhang L, Fang B: Mechanisms of resistance to TRAIL-induced apoptosis in cancer. Cancer Gene Ther 2005, I 2(3):228-237.

19. Sarkar FH, Li Y: NF-kappaB: a potential target for cancer chemoprevention and therapy. Front Biosci 2008, I 3:2950-2959.

20. Pahl HL: Activators and target genes of Rel/NF-kappaB transcription factors. Oncogene I999, I 8(49):6853-6866.

21. Falschlehner C, Emmerich CH, Gerlach B, Walczak H: TRAIL signalling: decisions between life and death. Int J Biochem Cell Biol 2007, 39(7-8): |462-|475.

22. Suh J, Rabson $A B$ : NF-kappaB activation in human prostate cancer: important mediator or epiphenomenon? J Cell Biochem 2004, 9 I(I): 100-II7.

23. Dai $Y$, Lawrence TS, Xu L: Overcoming cancer therapy resistance by targeting inhibitors of apoptosis proteins and nuclear factor-kappa B. Am J Transl Res 2009, I(I):4-I8.

24. Irmler M, Steiner V, Ruegg C, Wajant H, Tschopp J: Caspaseinduced inactivation of the anti-apoptotic TRAF I during Fas ligand-mediated apoptosis. FEBS Lett 2000, 468(2-3): I29-I33.

25. Holcik M, Gibson H, Korneluk RG: XIAP: apoptotic brake and promising therapeutic target. Apoptosis 200I, 6(4):253-26I.

26. Wu G, Chai J, Suber TL, Wu JW, Du C, Wang X, Shi Y: Structural basis of IAP recognition by Smac/DIABLO. Nature 2000, 408(6815): 1008-1012.

27. Liu Z, Sun C, Olejniczak ET, Meadows RP, Betz SF, Oost T, Herrmann J, Wu JC, Fesik SW: Structural basis for binding of Smac/DIABLO to the XIAP BIR3 domain. Nature 2000, 408(6815): $1004-1008$.

28. Srinivasula SM, Ashwell JD: IAPs: What's in a Name? Mol Cell 2008, 30:123-135.

29. Varfolomeev E, Blankenship JW, Wayson SM, Fedorova AV, Kayagaki N, Garg P, Zobel K, Dynek JN, Elliott LO, Wallweber HJ, Flygare JA, Fairbrother WJ, Deshayes K, Dixit VM, Vucic D: IAP antagonists induce autoubiquitination of c-IAPs, NF-kappaB activation, and TNFalpha-dependent apoptosis. Cell 2007, I 3 I (4):669-68I.

30. Vince JE, Wong WW, Khan N, Feltham R, Chau D, Ahmed AU, Benetatos CA, Chunduru SK, Condon SM, McKinlay M, Brink R, Leverkus M, Tergaonkar V, Schneider P, Callus BA, Koentgen F, Vaux DL, Silke J: IAP antagonists target cIAP I to induce TNFalphadependent apoptosis. Cell 2007, I 3 I (4):682-693.

31. Petersen SL, Wang L, Yalcin-Chin A, Li L, Peyton M, Minna J, Harran $P$, Wang $X$ : Autocrine TNFalpha signaling renders human 
cancer cells susceptible to Smac-mimetic-induced apoptosis. Cancer Cell 2007, I 2(5):445-456.

32. Bockbrader KM, Tan M, Sun Y: A small molecule Smac-mimic compound induces apoptosis and sensitizes TRAIL- and etoposide-induced apoptosis in breast cancer cells. Oncogene 2005, 24(49):738I-7388.

33. Petrucci E, Pasquini L, Petronelli A, Saulle E, Mariani G, Riccioni R, Biffoni M, Ferretti G, Benedetti-Panici P, Cognetti F, Scambia G, Humphreys R, Peschle C, Testa U: A small molecule Smac mimic potentiates TRAIL-mediated cell death of ovarian cancer cells. Gynecol Oncol 2007, I05(2):48I-492.

34. Sun H, Nikolovska-Coleska Z, Yang CY, Xu L, Liu M, Tomita Y, Pan $H$, Yoshioka Y, Krajewski K, Roller PP, Wang S: Structure-based design of potent, conformationally constrained Smac mimetics. J Am Chem Soc 2004, I 26(5 I): 16686-I6687.

35. Sun H, Nikolovska-Coleska Z, Yang CY, Xu L, Tomita Y, Krajewski K, Roller PP, Wang S: Structure-based design, synthesis, and evaluation of conformationally constrained mimetics of the second mitochondria-derived activator of caspase that target the X-linked inhibitor of apoptosis protein/caspase-9 interaction site. J Med Chem 2004, 47(I7):4I47-4I50.

36. Sun H, Nikolovska-Coleska Z, Lu J, Qiu S, Yang CY, Gao W, Meagher J, Stuckey J, Wang S: Design, synthesis, and evaluation of a potent, cell-permeable, conformationally constrained second mitochondria derived activator of caspase (Smac) mimetic. J Med Chem 2006, 49(26):79|6-7920.

37. Jia $G$, Zhan $Y, W u ~ D$, Meng $Y, X u L:$ An improved ultrasoundassisted extraction process of gossypol acetic acid from cottonseed soapstock. AIChE / 2009, 55(3):797-806.

38. Dai Y, Liu M, Tang W, Desano J, Burstein E, Davis M, Pienta K, Lawrence $\mathrm{T}, \mathrm{Xu} \mathrm{L}$ : Molecularly targeted radiosensitization of human prostate cancer by modulating inhibitor of apoptosis. Clin Cancer Res 2008, 14(23):770I-77I0.

39. Burstein E, Hoberg JE, Wilkinson AS, Rumble JM, Csomos RA, Komarck CM, Maine GN, Wilkinson JC, Mayo MW, Duckett CS: COMMD proteins, a novel family of structural and functional homologs of MURRI. J Biol Chem 2005, 280(23):22222-22232

40. Maine GN, Burstein E: COMMD proteins and the control of the NF kappa B pathway. Cell Cycle 2007, 6(6):672-676.

4I. Ji Q, Hao X, Meng Y, Zhang M, Desano J, Fan D, Xu L: Restoration of tumor suppressor miR-34 inhibits human p53-mutant gastric cancer tumorspheres. BMC Cancer 2008, 8(I):266.

42. Dai $Y$, DeSano JT, Meng Y, Ji Q, Ljungman M, Lawrence TS, Xu L: Celastrol potentiates radiotherapy by impairment of DNA damage processing in human prostate cancer. Int I Radia Oncol Biol Phys 2009, 74(4):1217-1225.

43. Ng CP, Bonavida B: X-linked inhibitor of apoptosis (XIAP) blocks Apo2 ligand/tumor necrosis factor-related apoptosisinducing ligand-mediated apoptosis of prostate cancer cells in the presence of mitochondrial activation: sensitization by overexpression of second mitochondria-derived activator of caspase/direct IAP-binding protein with low pl (Smac/DIABLO). Mol Cancer Ther 2002, I(I 2): I05 I- 058.

44. Nikolovska-Coleska Z, Xu L, Hu Z, Tomita Y, Li P, Roller PP, Wang R, Fang X, Guo R, Zhang M, Lippman ME, Yang D, Wang S: Discovery of embelin as a cell-permeable, small-molecular weight inhibitor of XIAP through structure-based computational screening of a traditional herbal medicine three-dimensional structure database. J Med Chem 2004, 47( I 0):2430-2440.

45. Naumann U, Bahr O, Wolburg H, Altenberend S, Wick W, Liston P, Ashkenazi A, Weller M: Adenoviral expression of XIAP antisense RNA induces apoptosis in glioma cells and suppresses the growth of xenografts in nude mice. Gene Ther 2007, I4(2):|47-|6I.

46. Mitsiades CS, Mitsiades N, Poulaki V, Schlossman R, Akiyama M, Chauhan D, Hideshima T, Treon SP, Munshi NC, Richardson PG, Anderson KC: Activation of NF-kappaB and upregulation of intracellular anti-apoptotic proteins via the IGF- I/Akt signaling in human multiple myeloma cells: therapeutic implications. Oncogene 2002, 21 (37):5673-5683.

47. Amantana A, London CA, Iversen PL, Devi GR: X-linked inhibitor of apoptosis protein inhibition induces apoptosis and enhances chemotherapy sensitivity in human prostate cancer cells. Mol Cancer Ther 2004, 3(6):699-707.

48. Mao HL, Liu PS, Zheng JF, Zhang PH, Zhou LG, Xin G, Liu C: Transfection of Smac/DIABLO sensitizes drug-resistant tumor cells to TRAIL or paclitaxel-induced apoptosis in vitro. Pharmacol Res 2007, 56(6):483-492.

49. Morales JC, Ruiz-Magana MJ, Ruiz-Ruiz C: Regulation of the resistance to TRAIL-induced apoptosis in human primary $\mathrm{T}$ lymphocytes: role of NF-kappaB inhibition. Mol Immunol 2007, 44( 10$)$ :2587-2597.

50. Braeuer S], Buneker C, Mohr A, Zwacka RM: Constitutively activated nuclear factor-kappaB, but not induced NF-kappaB, leads to TRAIL resistance by up-regulation of $X$-linked inhibitor of apoptosis protein in human cancer cells. Mol Cancer Res 2006, 4(10):715-728.

5I. Kuai J, Nickbarg E, Wooters J, Qiu Y, Wang J, Lin LL: Endogenous association of TRAF2, TRAF3, cIAPI, and Smac with lymphotoxin beta receptor reveals a novel mechanism of apoptosis. J Biol Chem 2003, 278( I6): | 4363-I4369.

52. Samuel T, Welsh K, Lober T, Togo SH, Zapata JM, Reed JC: Distinct BIR domains of cIAPI mediate binding to and ubiquitination of tumor necrosis factor receptor-associated factor $\mathbf{2}$ and second mitochondrial activator of caspases. J Biol Chem 2006, 28 I (2): I080-1090.

53. Bertrand MJ, Milutinovic S, Dickson KM, Ho WC, Boudreault A, Durkin J, Gillard JW, Jaquith JB, Morris SJ, Barker PA: cIAPI and cIAP2 facilitate cancer cell survival by functioning as $E 3$ ligases that promote RIP I ubiquitination. Mol Cell 2008, 30(6):689-700.

54. Ahn KS, Sethi G, Aggarwal BB: Embelin, an inhibitor of $\mathbf{X}$ chromosome-linked inhibitor-of-apoptosis protein, blocks nuclear factor-kappaB (NF-kappaB) signaling pathway leading to suppression of NF-kappaB-regulated antiapoptotic and metastatic gene products. Mol Pharmacol 2007, 7I(I):209-2I9

55. Johnstone RW, Ruefli AA, Lowe SW: Apoptosis: a link between cancer genetics and chemotherapy. Cell 2002, 108(2):153-164.

\section{Pre-publication history}

The pre-publication history for this paper can be accessed here:

\section{http://www.biomedcentral.com/1471-2407/9/392/pre} pub
Publish with Biomed Central and every scientist can read your work free of charge

"BioMed Central will be the most significant development for disseminating the results of biomedical research in our lifetime. "

Sir Paul Nurse, Cancer Research UK

Your research papers will be:

- available free of charge to the entire biomedical community

- peer reviewed and published immediately upon acceptance

- cited in PubMed and archived on PubMed Central

- yours - you keep the copyright
BioMedcentral 